\title{
Experimental analysis of load capacity in beams with steel fiber reinforcement on the compression face
}

\author{
Análise experimental da capacidade portante em \\ vigas com reforço de fibras de aço na face tracionada
}
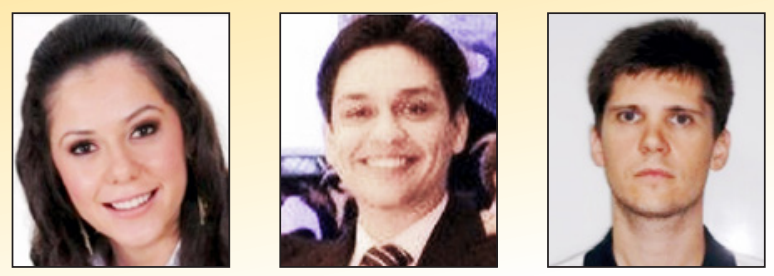

C. C. DEGHENHARD ${ }^{a}$ caroline.crozeta@gmail.com https://orcid.org/0000-0003-3718-5718

B. V. SILVA b

dovalesilva@hotmail.com https://orcid.org/0000-0001-5363-5657

F. PELISSER c

pelisser@hotmail.com https://orcid.org/0000-0002-6113-5473

\section{Abstract}

The use of steel fibers in the concrete is mainly aimed at increasing the post-peak toughness, due to the adhesion of the fibers to the cementitious matrix. However, there are several typologies of steel fibers, and the main differences are in the form (relation between length and diameter), fiber geometry, and the characterization between macrofibers and microfibers, which generally serve to reduce macrocracking and microcracking, respectively. In this context, this work evaluated the use of microfibers $\left(20 \mathrm{~kg} / \mathrm{m}^{3}\right.$ or volume equal to $0.26 \%\left(\mathrm{~V}_{\mathrm{f}}\right)$ of concrete volume), macrofibers $\left(20 \mathrm{~kg} / \mathrm{m}^{3}\right.$ or $\left.V_{f}=0.26 \%\right)$ and hybridization $\left(10 \mathrm{~kg} / \mathrm{m}^{3}\right)+$ macrofibers $\left(10 \mathrm{~kg} / \mathrm{m}^{3}\right)$ inserted in a high strength concrete $\left(f_{c}=80 \mathrm{MPa}\right)$. Two types of steel fibers were used: macrofibers with a diameter of $0.75 \mathrm{~mm}$ and a length of $60 \mathrm{~mm}$ (a form factor of 80); and microfibers with a diameter of $200 \mu \mathrm{m}$ and a length of $13 \mathrm{~mm}$ (a form factor of 65). The fibers were used in concrete to act as a reinforcement on the compression face of reinforced beams $(12 \times 20 \times 160 \mathrm{~cm})$, and the mechanical characteristics of the concretes were analyzed: (i) flexural strength in prismatic specimens $(10 \times 10 \times 35 \mathrm{~cm})$, (ii) compressive strength in cylindrical specimens $(20 \times \varnothing 10 \mathrm{~cm})$ and (iii) modulus of elasticity in cylindrical specimens $(20 \times \varnothing 10$ $\mathrm{cm})$. Analysis of the results showed that compressive strength increased by approximately $8 \%$ for all the compositions with fibers compared with concrete without fibers. Similar behavior was verified for the modulus of elasticity. In the prismatic specimens $(10 \times 10 \times 35 \mathrm{~cm})$ an increase in toughness was observed, with the macrofibers performing better. In beams measuring $12 \times 20 \times 160 \mathrm{~cm}$, an increase in bearing capacity was verified regarding cracking time and plastic rotation, with the best result also obtained using macrofibers. Overall, it can be concluded that the application of reinforcement with steel fibers in the compression face of beams was efficient, even though it did not present a significant increase in compressive strength, a fact that could be correlated with the reduced volume of fibers used.

Keywords: reinforcement, high-performance concrete, steel fibers, microfibers, macrofibers.

\section{Resumo}

A utilização de fibras de aço no concreto visa aumentar principalmente a tenacidade, em função da aderência das fibras à matriz cimentícia. Entretanto como existem diversas tipologias de fibras de aço, as principais diferenças estão no fator de forma (relação entre comprimento e diâmetro), na geometria das fibras, e, na caracterização entre macrofibras e microfibras, que de modo geral servem para reduzir a macrofissuração e microfissuração, respectivamente. Dentro deste contexto, este trabalho avaliou a utilização de microfibras $\left(20 \mathrm{~kg} / \mathrm{m}^{3}\right.$ ou volume igual a $0,26 \%\left(V_{f}\right)$ do volume de concreto), macrofibras $\left(20 \mathrm{~kg} / \mathrm{m}^{3}\right.$ ou $\left.V_{f}=0,26 \%\right)$ e a hibridização entre os dois tipos (microfibras $\left(10 \mathrm{~kg} / \mathrm{m}^{3}\right)+$ macrofibras $\left.\left(10 \mathrm{~kg} / \mathrm{m}^{3}\right)\right)$ inseridas em um concreto de alta resistência $\left(\mathrm{f}_{\mathrm{c}}=80 \mathrm{MPa}\right)$. Foram utilizados dois tipos de fibras de aço: as macrofibras com diâmetro de $0,75 \mathrm{~mm}$ e comprimento de $60 \mathrm{~mm}$ (fator de forma igual a 80, com gancho na extremidade); e microfibras com diâmetro de $200 \mu \mathrm{m}$ e comprimento de $13 \mathrm{~mm}$ (fator de forma igual a 65). As fibras foram utilizadas no concreto para atuar como reforço na face tracionada de vigas armadas $(12 \times 20 \times 160 \mathrm{~cm})$, e foram analisadas as características mecânicas dos concretos: (i) resistência à flexão em corpos de prova prismáticos $(10 \times 10 \times 35 \mathrm{~cm})$, (ii) resistência à compressão em corpos de prova cilíndricos $(20 \times \varnothing 10 \mathrm{~cm})$ e (iii) módulo de elasticidade em corpos de prova cilíndricos $(20 \times \varnothing 10 \mathrm{~cm})$. Análise dos resultados mostraram que na resistência à compressão houve um acréscimo de aproximadamente $8 \%$ para todas as composições com fibras em relação ao concreto sem fibras. Quanto ao módulo de elasticidade foi verificado comportamento semelhante. Nos corpos de prova prismáticos $(10 \times 10 \times 35 \mathrm{~cm})$ ocorreu aumento na tenacidade, sendo que as macrofibras tiveram melhor desempenho. Nas vigas de $12 \times 20 \times 160 \mathrm{~cm}$, ocorreu aumento da capacidade portante, quanto ao momento de fissuração e rotação plástica, sendo que o melhor resultado também foi obtido com as macrofibras. De modo geral, pode-se concluir que a aplicação do reforço com fibras de aço na face tracionada das vigas foi eficiente, embora não apresentou aumento significativo na resistência à compressão, fato que pode estar correlacionado ao reduzido volume de fibras utilizado.

Palavras-chave: reforço, concreto de alto desempenho, fibras de aço, microfibra, macrofibras. 


\section{Introduction}

When they are well designed and executed, reinforced concrete structures show great durability, yet they require preventive and corrective maintenance to ensure their functionality. In the construction industry, reinforcements are solutions used to avoid problems and to increase the carrying capacity of structural elements, which for numerous reasons no longer meet the requirements for which they were designed [1].

One of the ways to reinforce and improve the performance of concrete structures is the addition of fibers, which generally promote a gain in toughness, an increase in static tensile strength, dynamic fatigue and impact, traction, a reduction in demand deformations, and control of the number and speed of propagation of cracks. Together these effects contribute to the increased durability of the structure, since the presence of the fibers assists in reducing crack apertures, while also controlling and delaying their propagation, allowing for the stabilized occurrence of cracks.

Over time and through technological advances, different types of fibers have been investigated and developed, imbued with characteristics that made them more suitable for incorporation into concrete, which has allowed the development of a generation of composites with increasingly better properties, and with greatlyimproved performance compared with traditional concrete, in certain respects. In the most recent literature, for example, we find references to such terms as macrofibers and microfibers, used to differentiate larger and more resistant fibers, which act initially in post-cracking of the matrix, from smaller, more disseminated fibers, which act primarily in cracking delay [2]. An example of the contribution of the fibers in the flexural dimensioning of a reinforced concrete beam [3] showed a reduction in the area of steel area of 11,17 and $21 \%$, using fiber consumption of 20,30 and $45 \mathrm{~kg} / \mathrm{m}^{3}$, when using Dramix RC 80/60 steel fibers.

This topic isboth relevant and current, since many structures have been built with increased demand for strength and durability, or subject to the most varied demands arising from exceptional support or loading conditions. This study proposed evaluating the performance of steel microfibers, together with macrofibers, used in reinforced concrete as structural reinforcement.

\section{Fundamental aspects of fiber reinforced cement matrix composites}

The purpose of reestablishing a reinforced concrete structure is to return it to its original strength or increase its load capacity. Reinforcement is the act of correcting a structural or functional deficiency that often focuses solely on reducing the rate of deterioration. Finally, it is expected that a renovated and/or reinforced structure should perform better than it did before the intervention [4]. Steel fibers were chosen, as in work developed by Quinino [5], because they are the most widely used cement matrix reinforcement, due to the numerous benefits and economic importance of this material. Fibers act as a mechanism of tension transfer across cracks, allowing the concrete to present greater deformations under peak load and greater post-cracking load capacity, i.e. the ductility and residual resistance to traction of the material is increased [6]. According to Figueiredo [7], the random distribution of fibers in the material reinforces the structural element overall, in contrast to that which occurs with conventional reinforcements in reinforced concrete. It is important to emphasize that the use of the fibers as reinforcement is generally not considered to be sufficiently efficient to replace conventional reinforcement. In addition, it is imperative that aspects like matrix-fiber compatibility and adhesion are considered, to obtain the desired result.

For Martineau and Agopyan [8], fiber placement modifies the cracking process, acting as a transfer mechanism of forces across cracks, and ensuring minimal change in the load resistance capacity when these occur. Mehta and Monteiro [9] observed that even when fiber-reinforced concretes sustain deformations far superior to conventional concrete fracture deformation, they continue to withstand considerable loads, and the ultimate strength of the first crack depends heavily on matrix parameters and is influenced by the characteristics of the fiber. Doubts remain concerning the efficacy of fiber addition for improving ultimate strength; however, the consensus is that fibers improve the ductility of cementitious composites.

\section{Experimental methodology}

To begin, four groups were defined: i) reference concrete, without fibers (A); ii) concrete with macrofibers (B); iii) concrete with microfibers (C); and iv) concrete with micro and macrofibers (D). The following test specimens were produced for each group: two $12 \times 20 \times 160 \mathrm{~cm}$ reinforced concrete beams for 4-point bending tests; two cylindrical specimens $(20 \times \varnothing 10 \mathrm{~cm})$ for resistance to axial compression and modulus of elasticity; and two $10 \times 10 \times 35 \mathrm{~cm}$ prismatic specimens to determine the flexural strength of the concrete.

Flexural reinforcement was dimensioned according to the criteria of NBR 6118 [10], considering a compressive strength for concrete of $80 \mathrm{MPa}$ and CA-50 steel, adopting two $12.5 \mathrm{~mm}$ diameter bars for main reinforcement to resist flexural deformation. Stirrup spacing was $10.0 \mathrm{~cm}$ and $12.5 \mathrm{~cm}$ and the diameter was $5.0 \mathrm{~mm}$. In addition , $2.5 \mathrm{~cm}$ spacers were used to ensure reinforcement cover. Macrofibers measuring $600 \times 0.75 \mathrm{~mm}$ (form factor of 80 , trade name RC 80/60 BN, manufacturer ArcelorMittal/Dramix ${ }^{\circledR}$ ) were used in groups $B$ and $D$, and microfibers measuring $13 \mathrm{~mm} \times 200$ $\mu \mathrm{m}$ (form factor of 65 , trade name OL 13/.20, manufacturer ArcelorMittal/Dramix $\left.{ }^{\circledR}\right)$ were used in groups $C$ and $D$.

Concreting was done in two phases. In the first phase, only some of the beams $(12 \times 20 \times 160 \mathrm{~cm})$ from groups $B, C$, and $D$ were concreted. The beams of group $A$ (reference) were concreted in their entirety because they had no fiber reinforcement. The prismatic $(10 \times 10 \times 35 \mathrm{~cm})$ and the cylindrical specimens $(20 \times \varnothing 10 \mathrm{~cm})$ without fibers also were concreted together with this first phase. The concrete mix proportions were 1:2.3:2.7 cement:sand:gravel, with a water/cement (w/c) ratio of 0.4 . The cement used was type CPIV. The concrete was mixed in a $400 \mathrm{~L}$ concrete mixer. The consistency of the concrete was verified by the abatement test and was $11 \mathrm{~cm}$. All the beams were concreted simultaneously with concrete made in the laboratory and densified with immersion vibrators and a vibrating table. The beams were concreted up to a height of 13.75 $\mathrm{cm}$. This limit was controlled during the first concreting phase, by an internal mark inside the form, such that reinforcement used to resist flexural deformation in groups $B, C$ and $D$ was exposed. The 
reinforcement dimensions in groups $B, C$ and $D$ were determined to be twice that of the reinforcement cover plus the diameter of the reinforcement bar $(2.5+2.5+1.25=6.25 \mathrm{~cm})$. This dimension was maintained during the second phase of concreting (groups B, C, and $\mathrm{D}$ ), and only the type of fiber addition varied.

The second phase of concreting of the beams $(12 \times 20 \times 160 \mathrm{~cm})$ was done $24 \mathrm{~h}$ after the end of the first phase. The reconstitution of the tensioned face of the beams of groups $B, C$ and $D$ included the presence of fibers in $6.25 \mathrm{~cm}$ thickness defined above. The surface was not previously prepared since the stirrups served as the point of bonding for the new concrete. In the groups that received fiber reinforcement, the amount added was $20 \mathrm{~kg} / \mathrm{m}^{3}$ or $V_{f}=0.26 \%$ in relation to the concrete volume. The prismatic $(10 \times 10 \times 35 \mathrm{~cm})$ and cylindrical specimens $(20 \times \varnothing 10 \mathrm{~cm})$ with fiber additions were concreted together with this second phase.

Twenty-four hours after concreting, the cylindrical specimens were demolded and placed in submerged curing until 28 days of age, to test axial compressive strength [11] and modulus of elasticity [12]. The prismatic specimens and reinforced concrete beams were demolded 14 days after the final phase of concreting. They were painted to improve crack analysis. The age of rupture for all beams was 28 days after the second phase of concreting. The beams $(12 \times 20 \times 160 \mathrm{~cm})$ were identified as follows: group A, beams A1 and $A 2$; group $B$, beams $B 1$ and $B 2$; group $C$, beams $C 1$ and $C 2$; and group D, beams D1 and D2. Beams A1, B1, C1 and D1 refer to beams instrumented with strain gauges connected to the steel and concrete, while beams A2, B2, C2 and D2 had no sensors. The prismatic specimens $(10 \times 10 \times 35 \mathrm{~cm})$ were identified as $\mathrm{Ap}, \mathrm{Bp}, \mathrm{Cp}$, and $\mathrm{Dp}$, according to each group.

All the beams were submitted to the 4-point bending test. The loads were applied from top to bottom over a metal profile (Profile I $-10 \times 25.5 \mathrm{~cm}$ ) which transferred the load to the beams at two point loads precisely dividing the theoretical span of the beam into thirds. The beams were positioned under a metal reaction portal and the load was applied by an electrical hydraulic cylinder, with $500 \mathrm{kN}$ capacity. The load values were recorded by a load cell arranged between the hydraulic cylinder and the distribution beam (Profile I $-10 \times 25.5 \mathrm{~cm}$ ). The vertical displacements at 3 points (LVDT 1, LVDT 2 (center), LVDT 3) along the length of the beam were evaluated using linear variable differential transformers (LVDT). Deformations were monitored using strain gauges bonded to materials at strategic deformation points: concrete and flexural reinforcement (Figure 1). The equipment was connected to a Quantum $X^{\circledR}$ data acquisition system interface with $\mathrm{HBM}^{\circledR}$ catman ${ }^{\circledR}$ Easy software.

Verifications were made to analyze the behavior of each group at different time-points during load application: when the maximum displacement allowed (L/250) was reached, according to the norms, and at rupture. First, the load required to reach the maximum displacement allowed (L/250) was verified, considering $\mathrm{L}=150 \mathrm{~cm}$ as the theoretical span of the beams, which resulted in a displacement of $6.0 \mathrm{~mm}$. Lastly, the load and displacement that led the beam rupturing were verified. The experimental elastic line of the beam was determined using the bending test results - load curves vs vertical displacements - obtained with the LVDTs positioned along the beam length. Deformation values provide a better understanding of the limits of the deformation stages regarding bending moment of cracking and bending moment of plastification. A model was developed that characterized the phenomenon of change in deformation stages of a fiber-reinforced beam by observing the relationship between the bending moment and the curvature formed in the cross-section of the beam. Finally, the development of cracks and the form of rupture were mapped.

\section{Results and discussion}

\subsection{Reinforced concrete beams $(12 \times 20 \times 160 \mathrm{~cm})$}

\subsubsection{Loading and displacement at rupture}

The loads and the displacements verified at the rupture of the

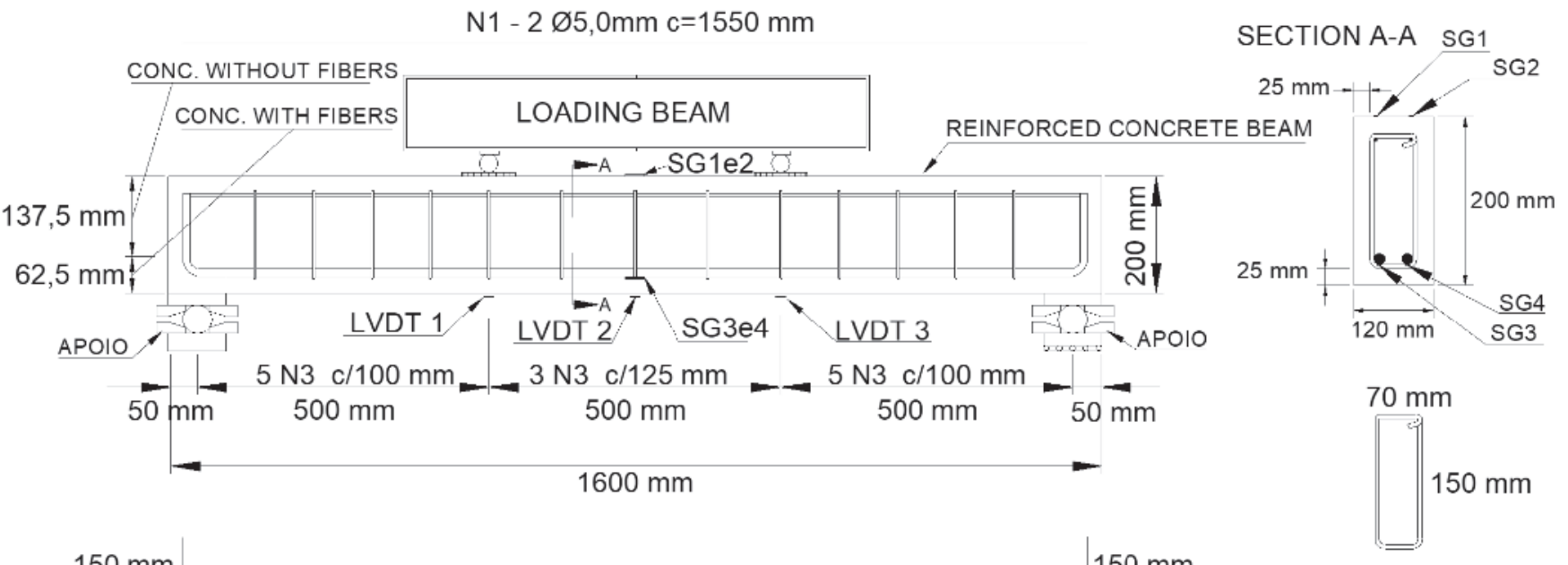

$150 \mathrm{~mm}$

$\mathrm{N} 2-2 \varnothing 12,5 \mathrm{~mm} \mathrm{c}=1850 \mathrm{~mm}$

$150 \mathrm{~mm}$

$\mathrm{N} 3-\varnothing 6,3 \mathrm{~mm} \mathrm{c}=440 \mathrm{~mm}$ $1550 \mathrm{~mm}$

Figure 1

Positions of the LVDTs and SGs along the beam 
Table 1

Results of loading and displacement of the beams at rupture $(12 \times 20 \times 160 \mathrm{~cm})$

\begin{tabular}{|c|c|c|c|c|c|}
\hline \multicolumn{6}{|c|}{ GROUP A - No fibers } \\
\hline Beams & Load (kN) & $\begin{array}{c}\text { Displacement left } \\
(\mathrm{mm})\end{array}$ & $\begin{array}{c}\text { Displacement middle } \\
(\mathrm{mm})\end{array}$ & $\begin{array}{c}\text { Displacement right } \\
(\mathrm{mm})\end{array}$ & Ductility factors \\
\hline Al & 84.22 & 13.77 & 16.91 & 15.48 & 1.98 \\
\hline A2 & 85.60 & 13.62 & 15.77 & 12.61 & 1.92 \\
\hline Mean (D.P) & $84.91(0.98)$ & $13.69(0.11)$ & $16.34(0.81)$ & $14.05(2.03)$ & $1.95(0.04)$ \\
\hline \multicolumn{6}{|c|}{ GROUP B - Macrofibers } \\
\hline Beams & Load $(\mathrm{kN})$ & $\begin{array}{l}\text { Displacement left } \\
(\mathrm{mm})\end{array}$ & $\begin{array}{l}\text { Displacement middle } \\
(\mathrm{mm})\end{array}$ & $\begin{array}{l}\text { Displacement right } \\
(\mathrm{mm})\end{array}$ & Ductility factors \\
\hline B1 & 89.09 & 14.33 & 18.30 & 16.07 & 2.00 \\
\hline B2 & 86.67 & 9.62 & 12.72 & 10.68 & 1.55 \\
\hline Mean (D.P) & $87.88(1.71)$ & $11.98(3.34)$ & $15.51(3.95)$ & $13.38(3.81)$ & $1.78(0.32)$ \\
\hline \multicolumn{6}{|c|}{ GROUP C - Microfibers } \\
\hline Beams & Load (kN) & $\begin{array}{c}\text { Displacement left } \\
(\mathrm{mm})\end{array}$ & $\begin{array}{l}\text { Displacement middle } \\
(\mathrm{mm})\end{array}$ & $\begin{array}{c}\text { Displacement right } \\
(\mathrm{mm})\end{array}$ & Ductility factors \\
\hline $\mathrm{Cl}$ & 88.88 & 11.20 & 14.39 & 11.67 & 1.77 \\
\hline $\mathrm{C} 2$ & 87.70 & 14.64 & 12.24 & 12.07 & 1.65 \\
\hline Mean (D.P) & $88.29(0.83)$ & $12.92(2.43)$ & $13.31(1.52)$ & $11.87(0.28)$ & $1.71(0.08)$ \\
\hline \multicolumn{6}{|c|}{ GROUP D - Macrofibers + Microfibers } \\
\hline Beams & Load (kN) & $\begin{array}{c}\text { Displacement left } \\
(\mathrm{mm})\end{array}$ & $\begin{array}{c}\text { Displacement middle } \\
(\mathrm{mm})\end{array}$ & $\begin{array}{c}\text { Displacement right } \\
(\mathrm{mm})\end{array}$ & Ductility factors \\
\hline D1 & 86.99 & 13.90 & 18.71 & 13.91 & 2.11 \\
\hline D2 & 85.16 & 11.37 & 14.21 & 11.74 & 1.85 \\
\hline Mean (D.P) & $86.07(1.29)$ & $12.63(1.79)$ & $16.46(3.18)$ & $12.83(1.54)$ & $1.98(0.18)$ \\
\hline
\end{tabular}

beams and the ductility factors are shown in Table 1 . The behavior of the percentages that justify the increase in bearing capacity between the groups was different in displacement up to rupture. To achieve rupture in the beams from group $B$, the load required was $3.5 \%$ higher than for group $A$, while group $C$ required $4.0 \%$ higher loads, and group $\mathrm{D}$ required $1.4 \%$ higher loads. Regarding displacements, these were very similar between all the groups. When analyzing the average values of loads at rupture (Figure 2), an increase was observed for beams $\mathrm{B}$ and $\mathrm{C}$ with macrofiber and microfiber

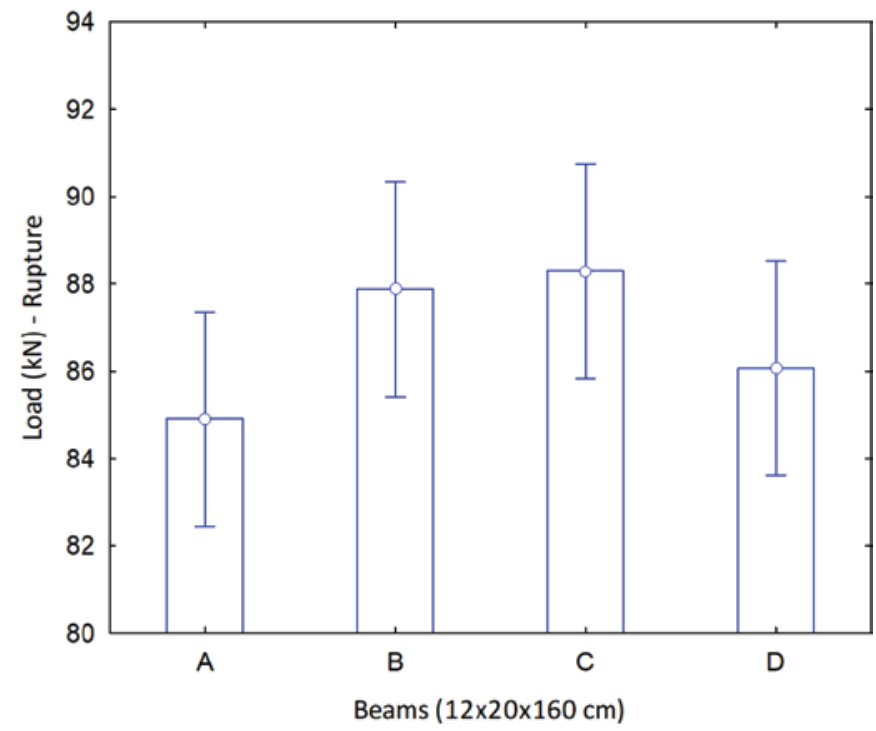

Figure 2

Analysis of load results at rupture - beams $(12 \times 20 \times 160 \mathrm{~cm})$ additions, respectively. Despite the lower form factor, microfibers showed a tendency to increase, which could be associated with larger amounts of fiber, and their efficiency at reinforcing concrete during microcracking provoked before rupture. When using macrofibers + microfibers (group D), a reduction in rupture load of the beam was observed, but it remained better than the reference beams (group A). Comparison between this result and beams with either macro

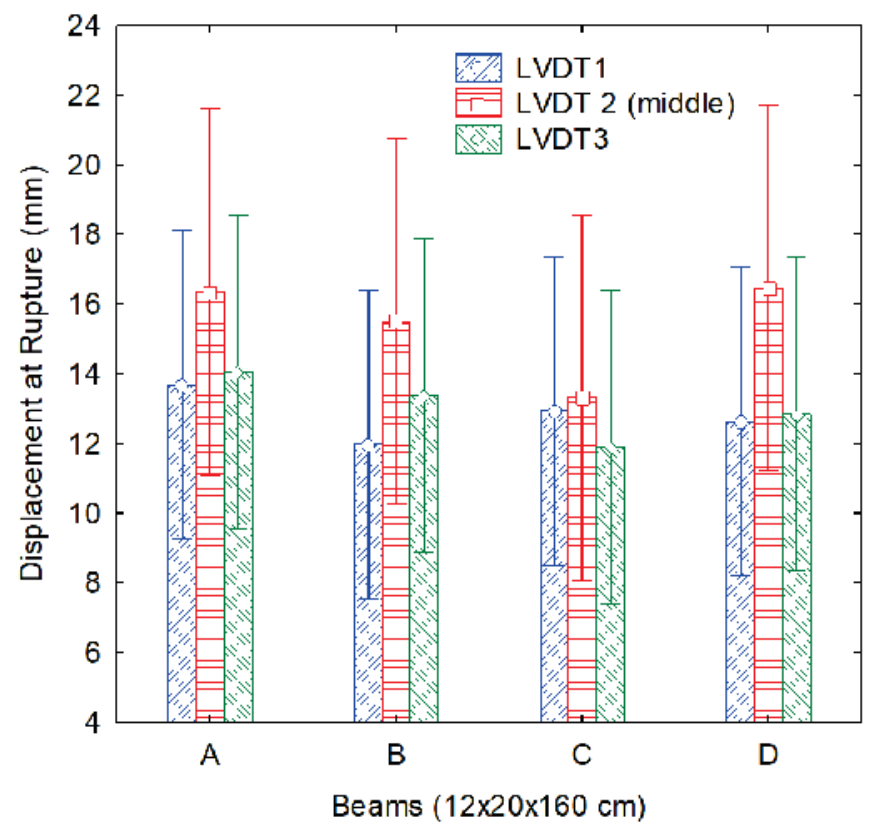

Figure 3

Analysis of the results of displacement at rupture in beams $(12 \times 20 \times 160 \mathrm{~cm})$ 
or microfibers suggests the most plausible explanation is a loss of strength due to the lower compactness of the composite cementitious matrix with both fibers. Regarding displacement in the beams at rupture, group $\mathrm{C}$ showed that microfibers did not contribute to an increase in the final displacement before rupture. The ductility factor, obtained between the ratio of displacement at rupture and displacement at the moment of plastification, determined that group $\mathrm{D}$ showed better behavior than reference group $\mathrm{A}$.

\subsubsection{Load behavior versus displacement}

Figure 4 presents the load versus displacement of all beams $(12 \times 20 \times 160 \mathrm{~cm})$. The behaviors between the groups were similar for the ultimate loads and the service loads (L/250). The beams of all groups exceeded the maximum displacement allowed according to current norms $(\mathrm{L} / 250=6.0 \mathrm{~mm})$ before coallapsing. All the beams broke by crushing concrete on the compressed face.

The sequence of images in Figure 5 illustrates the particularities of the form of rupture and cracks in the four groups of beams $(12 \times 20 \times 160 \mathrm{~cm})$. The reference group A (no fibers in the traction face) presented the largest number of visible cracks, which surpassed the middle third region. Groups B, C, and D were similar regarding the appearance of cracks concentrated in the middle third of the theoretical span of the beam, and the appearance of some shear cracks.
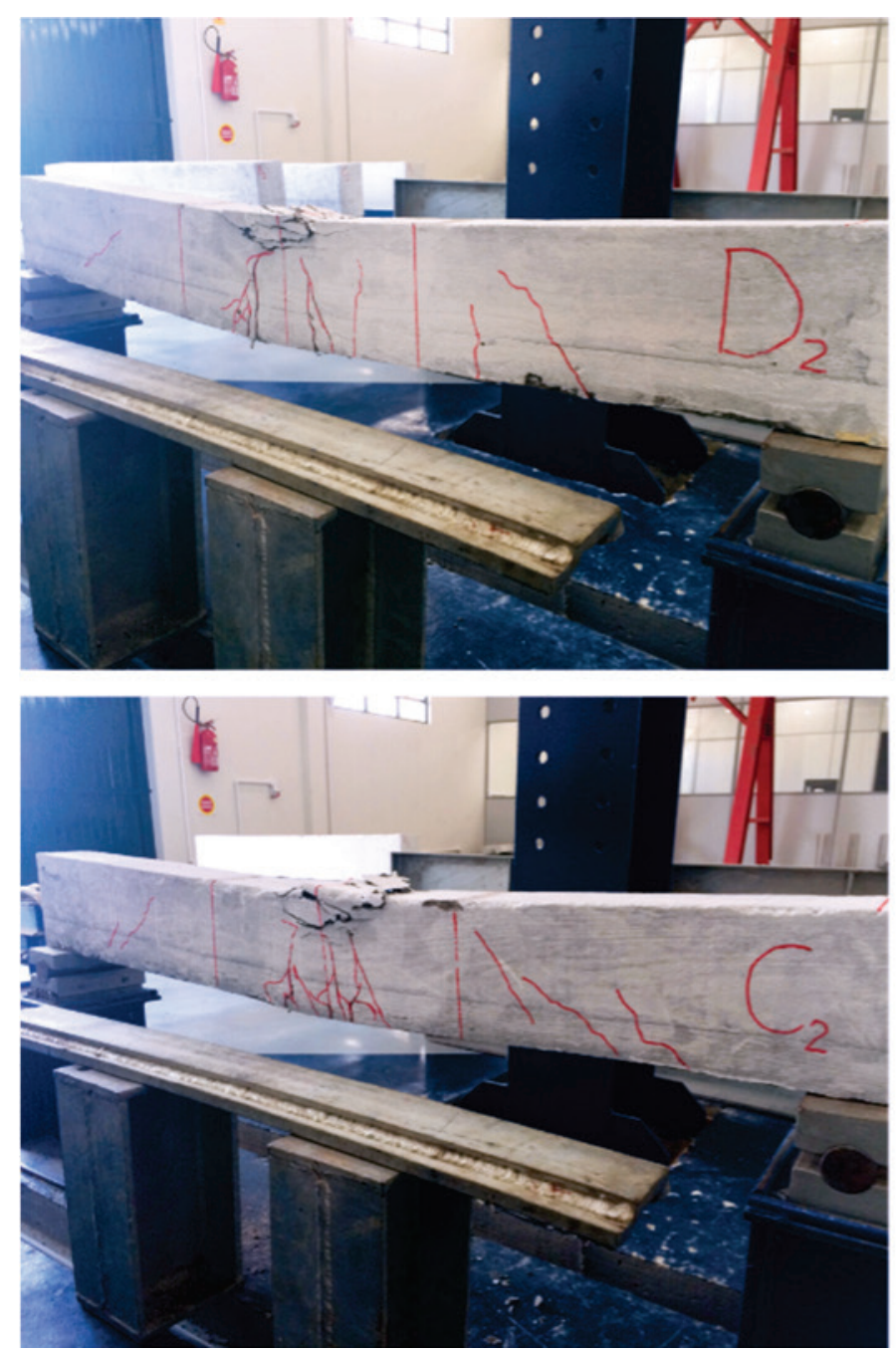

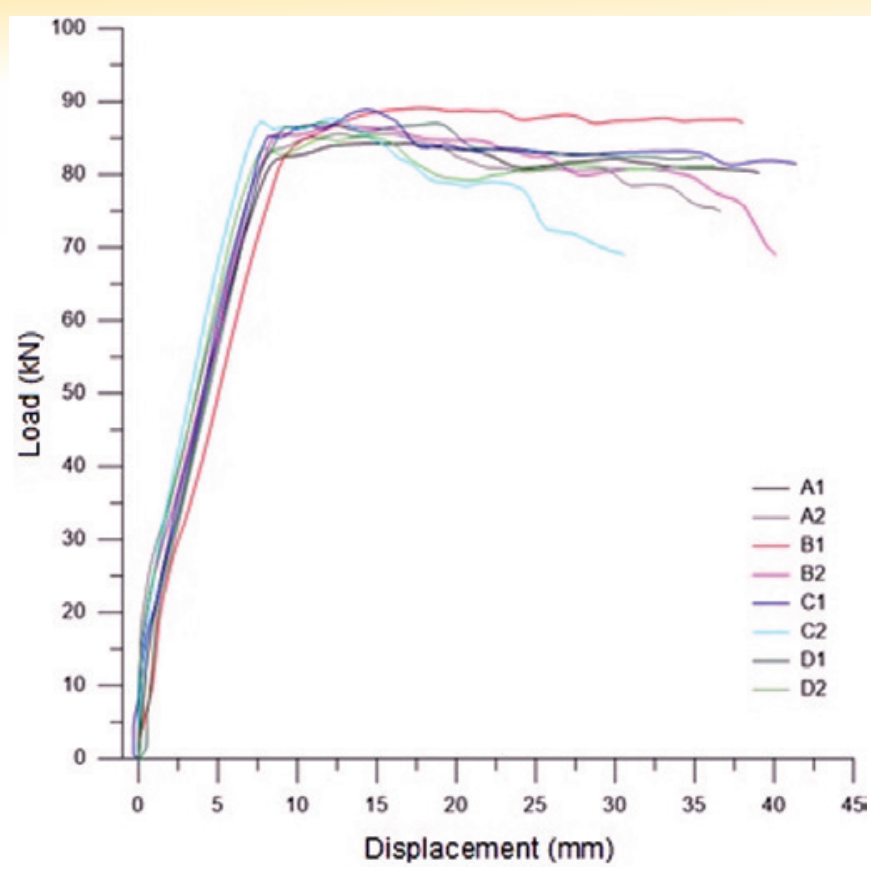

Figure 4

Load versus displacement behavior in beams $(12 \times 20 \times 160 \mathrm{~cm})$
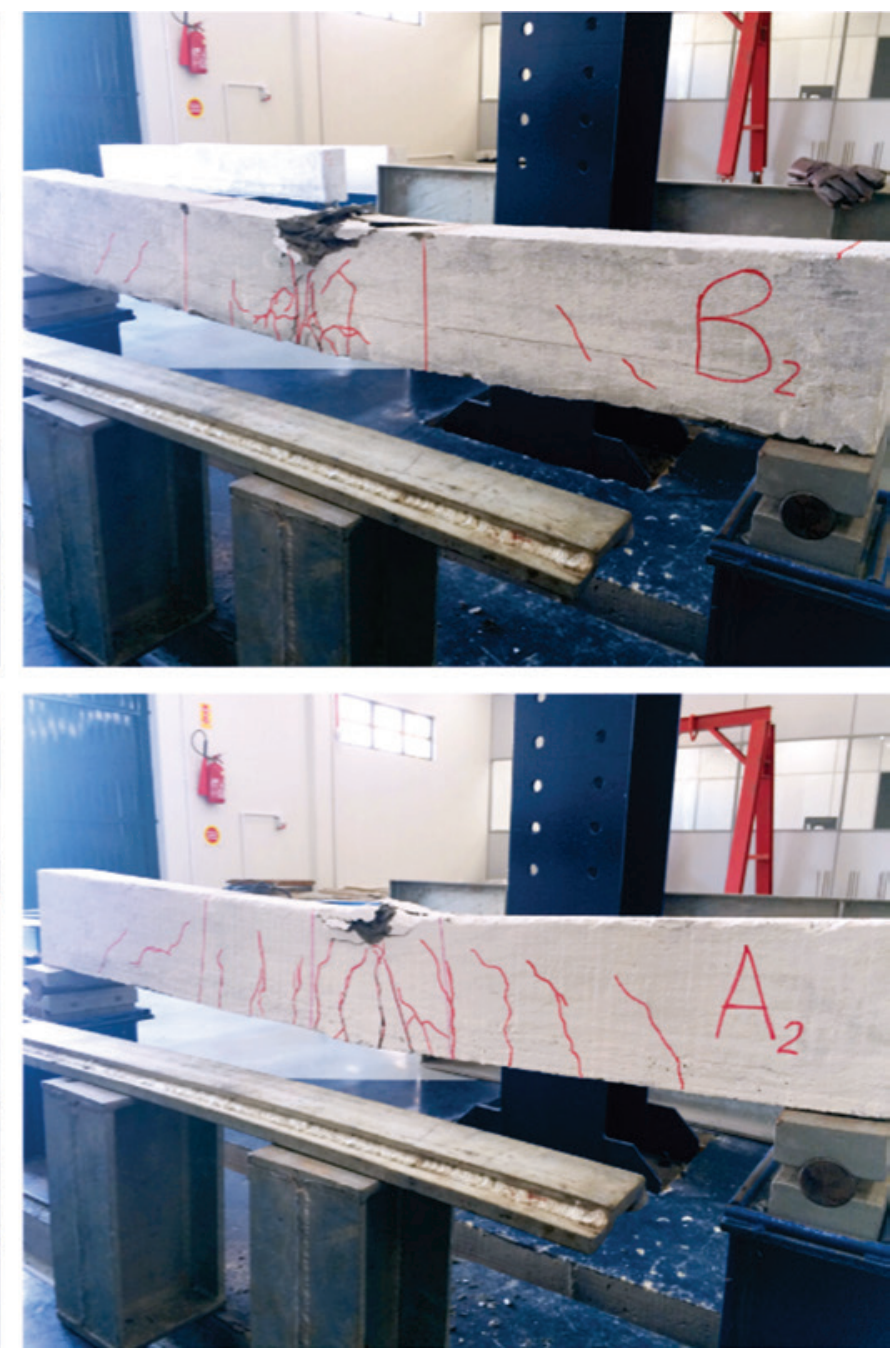

Figure 5

Form of rupture and cracks in beams $(12 \times 20 \times 160 \mathrm{~cm})$ 


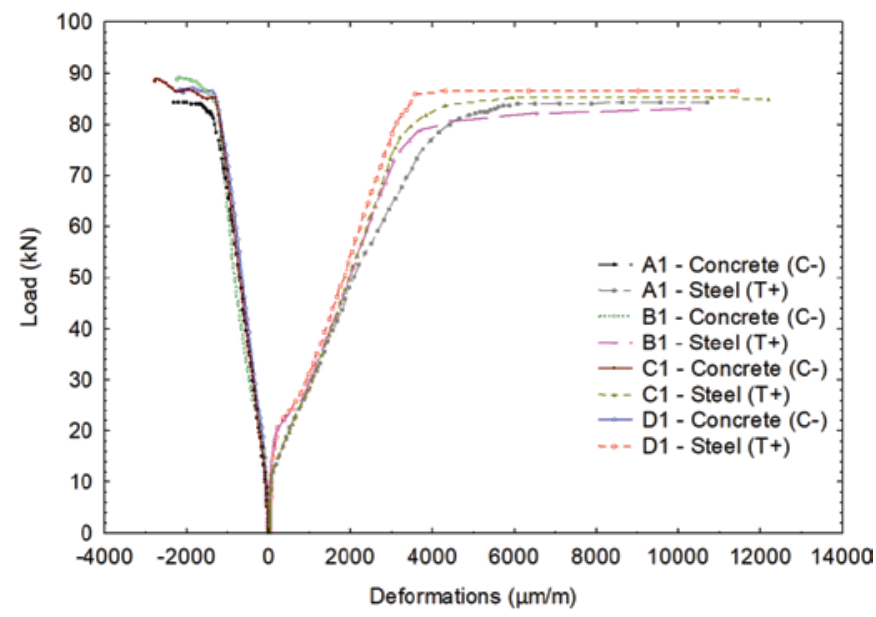

\section{Figure 6}

Specific deformations of steel and concrete in beams $(12 \times 20 \times 160 \mathrm{~cm})$

\subsubsection{Analysis of specific deformations}

Figure 6 shows specific deformations in the concrete in the uppermost compressed face and that of the steel in the lower, most tensioned face (steel bar, $\varnothing 12.5 \mathrm{~mm}$ ), both located in the central cross section (Figure 1). Note that the final deformations in concrete and steel were similar between the groups, approximately $2200 \mu \mathrm{m} / \mathrm{m}$ for concretes and $11000 \mu \mathrm{m} / \mathrm{m}$ for steels. However, groups $\mathrm{B}$ and $\mathrm{D}$ presented a smaller steel deformation between loads of $10 \mathrm{kN}$ and $20 \mathrm{kN}$, which contributed to increasing the period of cracking. When a loading value was set between 10 and 20 $\mathrm{kN}$, the smallest deformation (steel) occurred in the beams with the micro and macrofibers, followed by beams only with microfibers, only with macrofibers and finally, the reference concrete. These results show the potential of using microfibers in conjunction with macrofibers to improve the structural behavior of the reinforcement, before and after the occurrence of cracks. Recent research has shown the beneficial effect of using hybrid fibers - macro and

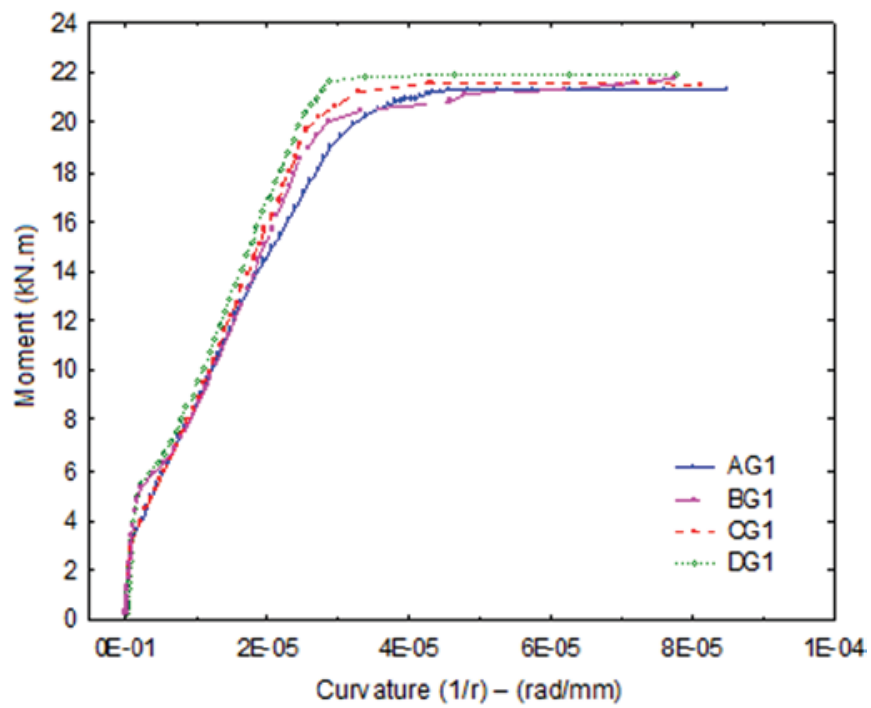

Figure 7

Bending moment-curvature diagram for beams $(12 \times 20 \times 160 \mathrm{~cm})$

microfibers - to improve the resistance to deformation in multiple cracking states [13].

\subsubsection{Analysis of the bending moment-curvature diagram}

Table 2 presents the results of moments and curvatures and the differences in percentages regarding the reference beam, while Figure 7 shows the bending moment-curvature diagrams for beams A1, B1, C1 and D1. Group B (+ macrofibers) presented 6.5 times greater cracking time than group A (reference), followed by groups $D$ and $C$. Regarding rotation, the results for cracking time-points (Mr) in group B were 19.6 times higher than group A (reference), followed by groups $D$ and $C$. This behavior shows that fibers increased the time of cracking and plastic rotation, but the isolated addition of microfibers contributed the least. The geometry

\section{Table 2}

Results of the bending moments and curvatures of the beams $(12 \times 20 \times 160 \mathrm{~cm})$

\begin{tabular}{|c|c|c|c|c|c|c|}
\hline \multicolumn{7}{|c|}{ Moments } \\
\hline Beams & $\begin{array}{c}\text { Moment } \\
\text { of cracking } \\
M_{r}(k N . m)\end{array}$ & Difference & $\begin{array}{c}\text { Moment of } \\
\text { plastification } \\
M_{y}(k N . m)\end{array}$ & Difference & $\begin{array}{l}\text { Moment } \\
\text { of rupture } \\
M_{u}(k N . m)\end{array}$ & Difference \\
\hline A & 0.7 & Ref. & 20.6 & Ref. & 21.3 & Ref. \\
\hline $\mathrm{B}$ & 5.4 & $+655.7 \%$ & 20.5 & $-0.7 \%$ & 22.6 & $+5.7 \%$ \\
\hline C & 2.8 & $+291.8 \%$ & 19.1 & $-7.1 \%$ & 22.5 & $+5.5 \%$ \\
\hline $\mathrm{D}$ & 4.5 & $+529.6 \%$ & 21.7 & $+5.3 \%$ & 22.0 & $+3.2 \%$ \\
\hline \multicolumn{7}{|c|}{ Curvature in moments } \\
\hline Beams & $1 / \mathrm{r}\left(\mathrm{M}_{\mathrm{r}}\right)$ & Difference & $1 / \mathrm{r}\left(\mathrm{M}_{\mathrm{y}}\right)$ & Difference & $1 / r\left(M_{u}\right)$ & Difference \\
\hline A & 1.15E-07 & Ref. & $3.57 \mathrm{E}-05$ & Ref. & $7.65 \mathrm{E}-05$ & Ref. \\
\hline $\mathrm{B}$ & $2.37 \mathrm{E}-06$ & $+1960.9 \%$ & 3.32E-05 & $-7.1 \%$ & $8.16 \mathrm{E}-05$ & $+6.6 \%$ \\
\hline C & 7.95E-07 & $+592.2 \%$ & 2.47E-05 & $-30.8 \%$ & 8.85E-05 & $+15.7 \%$ \\
\hline $\mathrm{D}$ & $1.45 \mathrm{E}-06$ & $+1161.2 \%$ & 2.90E-05 & $-18.8 \%$ & 7.95E-05 & $+3.9 \%$ \\
\hline
\end{tabular}




\section{Table 3}

Results of compressive strength and modulus of elasticity $(20 \times \varnothing 10 \mathrm{~cm})$

\begin{tabular}{|c|c|c|c|c|c|}
\hline Samples & $f_{c}(M P a)$ & Difference & $E_{c}(G P a)$ & Difference & Compositions \\
\hline $\mathrm{Al}$ & 81.8 & - & 54.2 & Ref. & Concrete \\
\hline A2 & 80.6 & - & - & - & Concrete \\
\hline Mean (D.P.) & $81.2(0.85)$ & Ref. & - & - & Concrete \\
\hline Samples & $f_{c}(M P a)$ & Difference & $E_{c}(G P a)$ & Difference & Compositions \\
\hline B1 & 86.3 & - & 57.3 & $+5.7 \%$ & Concrete + Macrofibers \\
\hline B2 & 89.3 & - & - & - & Concrete + Macrofibers \\
\hline Mean (D.P.) & $87.8(2.12)$ & $+8.1 \%$ & - & - & Concrete + Macrofibers \\
\hline Samples & $f_{c}(M P a)$ & Difference & $E_{c}(G P a)$ & Difference & Compositions \\
\hline $\mathrm{Cl}$ & 86.8 & - & 57.2 & $+5.5 \%$ & Concrete + Microfibers \\
\hline C2 & 89.6 & - & - & - & Concrete + Microfibers \\
\hline Mean (D.P.) & $88.2(1.98)$ & $+8.6 \%$ & - & - & Concrete + Microfibers \\
\hline Samples & $f_{c}(M P a)$ & Difference & $E_{c}(G P a)$ & Difference & Compositions \\
\hline D1 & 88.4 & - & 55.4 & $+2.2 \%$ & Concrete + Macrofibers + Microfibers \\
\hline D2 & 88.3 & - & - & - & Concrete + Macrofibers + Microfibers \\
\hline Mean (D.P.) & $88.4(0.07)$ & $+8.8 \%$ & - & - & Concrete + Macrofibers + Microfibers \\
\hline
\end{tabular}

of macrofibers, with their hooks and non-smooth surfaces, unlike microfibers, contribute to this property [13].

\subsection{Mechanical properties of the concretes}

\subsubsection{Compressive strength $\left(f_{c}\right)$ and modulus of elasticity $\left(E_{c}\right)$}

To mechanically characterize the concrete, tests to determine compressive strength and modulus of elasticity were performed. For compressive strength, the maximum difference between the groups was $8.8 \%$, and the concretes with fiber addition showed very similar results to each other, and were approximately $8 \%$ better than the reference concrete, without fibers (Table 3 ). According to Mehta and Monteiro [9], increasing the amount of steel fibers in concrete using contents less than $2 \%$ of volume exerts minimal influence on the compressive strength. However, for high strength concretes, an increase in compressive strength was verified for a concentration of $0.5 \%$ microfibers [14]. A study by Su et al. [14] used a maximum of $2.5 \%$ of two types of steel microfibers, with form factors of 50 $(6 \times 0.12 \mathrm{~mm})$ and $125(15 \times 0.12 \mathrm{~mm})$, and achieved compressive strengths of $114 \mathrm{MPa}$ and $145 \mathrm{MPa}$, respectively. In this work, the form factor of the microfibers was $65(13 \times 0.2 \mathrm{~mm})$, and a lower concentration of fibers was used. The increase resistance obtained was satisfactory, and was associated with greater resistance to the propagation of microcracks during loading.

Concerning the modulus of elasticity, the maximum difference between the groups was smaller, approximately $6 \%$ (Table 3 ), between the concrete with macrofibers and microfibers (groups $B$ and $\mathrm{C}$ ), than for the concrete without fibers. This difference may have been caused by the higher density of the concrete with fibers.

\subsubsection{Flexural test - prismatic test bodies $(10 \times 10 \times 35 \mathrm{~cm})$}

Regarding load and displacement at rupture (Figures 8 and 9, re- spectively), groups $C$ and $D$ achieved higher loads for displacement at rupture; load was $13 \%$ higher in group $C$ than in group $A$, with mean displacement of $0.27 \mathrm{~mm}$, while group $D$ showed a load increase of $8 \%$, with mean displacement of $0.30 \mathrm{~mm}$. Group B showed no increase in resistance in relation to group A. Again, a tendency for increased resistance to cracking, when using microfibers or microfibers plus macrofibers, was verified compared with the reference concrete. When using prismatic specimens, rather than reinforced concrete beams, this improvement was more evidently promoted by microfibers. Although the differences were small, fiber volume was also low $(\mathrm{Vf}=0.26 \%)$. This low amount was used because the

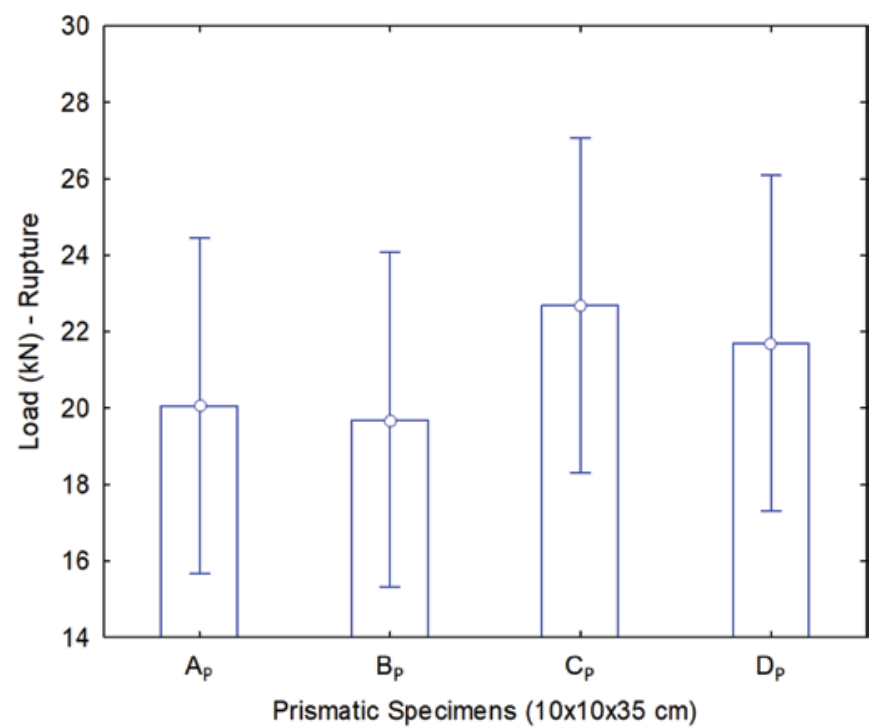

Figure 8

Analysis of the load results on the rupture in prismatic specimens $(10 \times 10 \times 35 \mathrm{~cm})$ 


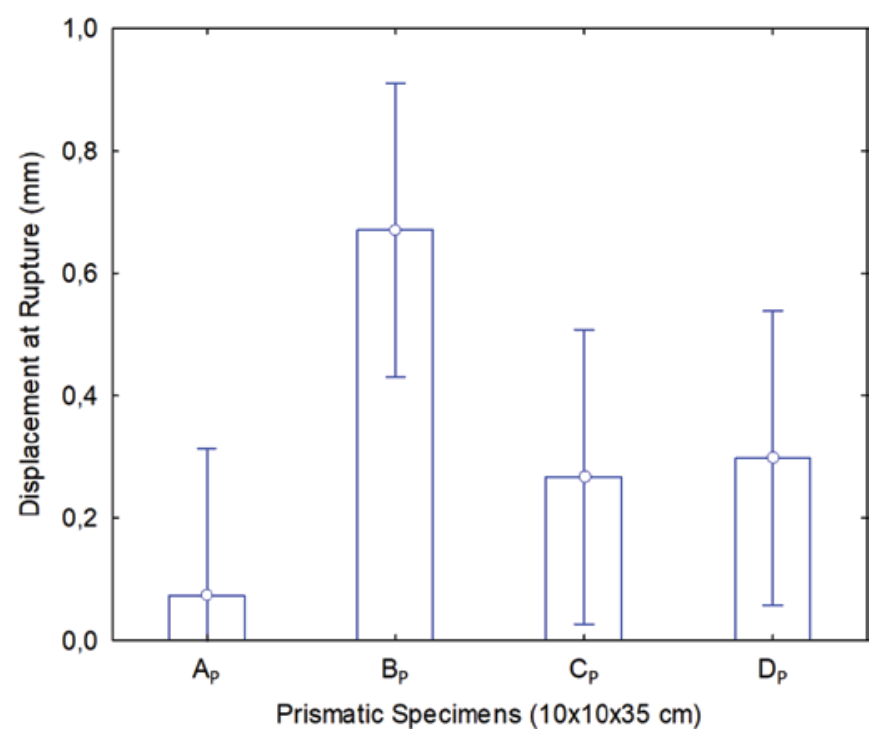

\section{Figure 9}

Analysis of the results of displacement at rupture in prismatic specimens $(10 \times 10 \times 35 \mathrm{~cm})$

concrete being tested had reinforcement, thus maintaining the ease of application. Similar behavior was observed in displacement up to rupture among prismatic specimens with fibers, wherein specimens with microfibers presented the best results.

The results for toughness are presented in Figures 10 and 11 and show a higher index for group $B$ (+ macrofibers). Groups $C$ and $D$ presented lower values than group $B$ and higher than the group $A$. The higher toughness caused by macrofibers can be explained by its higher form factor and the consequently larger fiber-matrix contact area. In addition, macrofibers have hooks which improve the post-cracking resistance of the concrete when compared with smooth fibers [13].

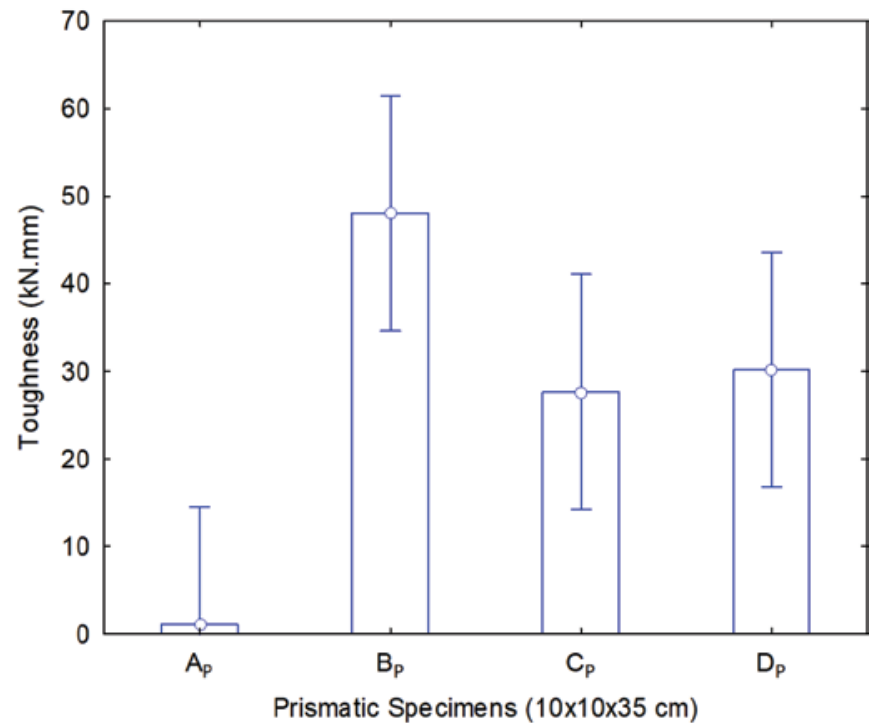

Figure 10

Analysis of toughness results in

prismatic specimens $(10 \times 10 \times 35 \mathrm{~cm})$

\section{Final considerations}

Regarding the results obtained, the following conclusions can be drawn:

- Regarding the loading and displacement results (according to the $\mathrm{L} / 250$ norm and at rupture) obtained for reinforced concrete beams $(12 \times 20 \times 160 \mathrm{~cm})$ and concrete beams $(10 \times 10 \times 35 \mathrm{~cm})$, the results improved for all the groups containing steel fibers on the tensioned face;

- In the bending moment-curvature diagram, both fibers increased cracking time and plastic rotation;

- Cracks in the $10 \times 10 \times 35 \mathrm{~cm}$ beams indicate that group A presented fragile behavior, leading to abrupt rupture;

- Compressive strength results were higher (8\%) for concretes with fiber additions;

- Macrofibers presented the best results compared with the remaining groups, for $12 \times 20 \times 160 \mathrm{~cm}$ and $10 \times 10 \times 35 \mathrm{~cm}$ beams;

- Comparing microfiber addition with macrofiber addition, microfibers improved the flexural strength and displacements of reinforced beams and improved compressive strength despite the low volume used. Macrofibers were better for increasing toughness or behavior after rupture;

- Use of a hybrid fiber addition - macrofibers + microfibers - did not present significantly differentiated behavior than when the fibers were used alone, but this combination did contribute to improvements in the region of microcracking and post-cracking, though to a less significant extent.

Finally, the method of applying reinforcement with steel fibers on the tensioned face of the beams proved to be effective, though it did not present increments of high resistance. The fibers contributed numerous results and were particularly efficient at combating cracking.

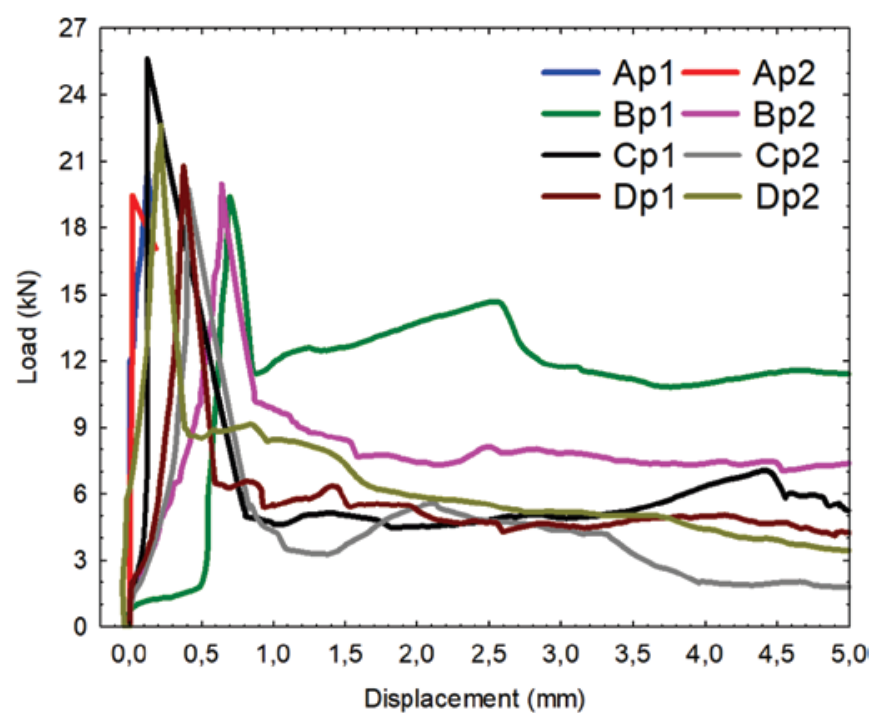

Figure 11

Load versus displacement behavior in prismatic specimens $(10 \times 10 \times 35 \mathrm{~cm})$ 


\section{Acknowledgements}

The authors are grateful for the financial support of the National Council for Scientific and Technological Development (CNPq) and to Belgo Bekaert for donating the fibers used herein.

\section{References}

[1] DEGHENHARD, C. C., TEIXEIRA, T., VARGAS, A., VITO, M., PICCININI, Â. C., DO VALE SILVA, B. Experimental analysis of various configurations of metal sheets in the reinforcement of flexion of reinforced concrete beams. ALCONPAT Journal, v. 6, p. 105-199, 2016.

[2] BERNARDI, S. T. Avaliação do comportamento de materiais compósitos de matrizes cimentícias reforçadas com fibra aramida Kevlar, 2003. Dissertação (Mestrado) - Escola de Engenharia da Universidade Federal do Rio Grande do Sul. Porto Alegre, 2003.

[3] REAL, L.V., NOGUEIRA, A.B., SIMÃO, L., FIGUEIREDO, A.D. Contribuição das fibras de aço para o dimensionamento à flexão de viga armada. Revista Concreto \& Construções, n 87, 2017.

[4] FERRARI, V.J., HANAI, J.B. Flexural strengthening of reinforced concrete beams with carbon fibers reinforced polymer (CFRP) sheet bonded to a transition layer of high performance cement-based composite. IBRACON Structures and Materials Journal. v.5, n.5, p. 596-626, 2012.

[5] QUININO, U. C. M. Investigação experimental das propriedades mecânicas de compósitos de concreto com adições híbridas de fibras. Tese (Doutorado em Engenharia Civil) Programa de Pós Graduação em Engenharia Civil (UFRGS) Universidade Federal do Rio Grande do Sul (UFRGS), Porto Alegre/RS, 2015.

[6] FIGUEIREDO, A.D. Concreto reforçado com fibras, Tese de Livre-Docência, Escola Politécnica, Universidade de São Paulo, São Paulo, 2011.

[7] FIGUEIREDO, A.D. Concreto com fibras. Concreto, Ensino, Pesquisa e Realizações, São Paulo, Ed. Geraldo Cechella Isaia, IBRACON, p.1194-1225, 2005.

[8] MARTINEAU, P., AGOPYAN, V. Conferência Magma I - Compósitos: material inovador. In: Arquimacom'2002. São Paulo, 2002.

[9] MEHTA, P. K. \& MONTEIRO, P. J. M. Concreto: Microestrutura, propriedades e materiais. $2^{\circ}$ Edição (português). São Paulo, IBRACON, 2014.

[10] ASSOCIAÇÃO BRASILEIRA DE NORMAS TÉCNICAS. NBR 6118: Projeto de estruturas de concreto. Rio de Janeiro, 2014.

[11] ASSOCIAÇÃO BRASILEIRA DE NORMAS TÉCNICAS. NBR 5739: Concreto - Ensaio de compressão de corpos de prova cilíndricos. Rio de Janeiro, 2014.

[12] ASSOCIAÇÃO BRASILEIRA DE NORMAS TÉCNICAS. NBR 8522: Concreto - Determinação do módulo estático de elasticidade à compressão. Rio de Janeiro, 2014.

[13] PARK, S. H., KIM, D.J., RYU, G. S., KOH K. T. Tensile behavior of Ultra High Performance Hybrid Fiber Reinforced Concrete. Cement \& Concrete Composites 34, 172-184, 2012.
[14] SU, Y., LI, J., WU, C. WU, P. LI, Z-X. Effects of steel fibres on dynamic strength of UHPC. Construction and Building Materials $114,708-718,2016$. 